\title{
Effect of Firm Characteristic to Profitability in PT Indofood Cbp Sukses Makmur Tbk And PT Mayora Indah Tbk
}

\author{
Wiwiek Mardawiyah Daryanto ${ }^{1}$, Donna Kartiningsih ${ }^{2 *}$, Eka Lestari $^{3}$ \\ ${ }^{1}$ Sekolah Tinggi Manajemen Ipmi, Jakarta, Indonesia 12750 \\ ${ }^{2,3}$ School of Business and Management, Institut Teknologi Bandung, Jakarta 12950
}

\begin{abstract}
A B S T R A C T
This research is aims to examine, analyze, and find the empirical evidence of the influence of firm characteristic proxied by firm age, firm size, sales growth, liquidity, and leverage on profitability proxied by return on sales in PT Indofood CBP Sukses Makmur Tbk and PT Mayora Indah Tbk. The study using employed multiple regression as tool for the analysis. The results of this study show that firm age, liquidity, and leverage have significant effect on profitability. However, the firm size and sales growth has no effect on profitability.
\end{abstract}

ART I CLE IN F O

Keywords:

Firm Characteristic,

Firm Age,

Firm Size,

Sales Growth,

Liquidity,

Leverage And Profitability.

*Corresponding Author E-mail: donna_kartiningsih@sbm-itb.ac.id

\section{INTRODUCTION}

The rapid development of the business world makes the company's needs accounting even higher, because accounting is an information system that gives report about the activities and performance of a company in one period. Companies that have go-public have an obligation to present their financial reports in accordance with the requirements set by the authorized institutions in Indonesia, namely OJK (Otorisasi Jasa Keuangan). Financial reports are useful for providing information to the parties that need, such as internal parties to make decisions in running the company, external parties such as investors to help provide information in making decisions whether to invest in the company or not (Belkaoui, 2006).
According to Belkaoui (2006) the purpose of financial statements is to convey information whether the management of the company has used capital effectively to achieve the company's main objectives. One of the important information contained in financial report is information about profits. Profitability can show how well a company's ability to generate profits. Profitability is used to measure the efficiency of the capital in a company by comparing between the profit with the capital used in operations. The company always expects high profitability and increase every year.

A good company, if the company can operate stably over a long period of time so that they will 
not have difficulty on returning their debts, both short-term debt and long-term debt. Therefore, the company must know the factors that can affect the profitability of the company, in this research the factors that can affect the profitability of the company are the firm characteristics, which proxied by firm age, firm size, sales growth, liquidity, and leverage.

This research based on research by Charles, Ahmed, and Joshua (2018), Effect of Firm Characteristics on Profitability of Listed Consumer Goods Companies in Nigeria. That research found that firm size, sales growth and leverage have significant effects on profitability. In contrast, firm age and liquidity are not significantly affecting profitability of listed consumer goods companies in Nigeria.

The Research by Miswanto, Abdullah and Suparti (2017) they found that Working Capital Turnover (WCT) has a positive and significant effect on profitability. The growth of the Company which is proxied by sales growth has negative and insignificant effect on profitability. firm size has a positive and significant effect on profitability.

Another research by Putra and Badjra (2015) about the effect of leverage, sales growth and company size on profitability in food and beverage industry companies listed on IDX for the period 2008-2013. This research found that leverage has negative and significant effect on profitability, sales growth has negative but not significant effect on profitability, and the size of the company has negative but not significant to profitability.

The results of previous research indicate difference result, it became of interest to the researchers to examine the effect of these firm characteristics proxied by firm age, firm size, liquidity, sales growth and leverage on the profitability in 2 popular FMCG companies in Indonesia, PT. Indofood CBP Sukses Makmur Tbk and PT. Mayora Indah Tbk from 2011-2017.

This research is organized into five sections. Section one captures the introduction, section two review of related literature about the theoretical basis, profitability and firm characteristics, section three discuss the research methodology, section four discuss the finding result and analysis, section five captures the conclusion of this research.

\section{LITERATURE REVIEW}

\section{Resource based Theory}

This research is support by Resource based Theory proposed by Wernerfelt in 1984. According to Wernerfelt (1984) in Wahyuni and Pujiharto (2015) explained that in the view of Resource Based Theory, a company gain competitive advantage and good financial performance by owning, mastering and utilizing important strategic assets, including the tangible assets, the intangible assets and capabilities of the company itself. If the company can utilize the resources maximumly, the company will have a competitive advantage and be able to compete with its competitors.

\section{Profitability}

Profitability is the company's ability to generate profits at certain periods. The company's ability to generate profits in its operations is the main focus in the company's performance appraisal (company fundamental analysis) because the company's profit is not only an indicator of the company's ability to fulfill its obligations for its funders, but also is the review about the company in the future.

\section{Firm Age}

According to Annisa (2016) Firm age is the length of life of a company that shows that the company still exists, able to compete in the business world and capable maintain the continuity of its business and is part of documentation that shows the purpose of the company. Firm age is calculated from the beginning when the company was founded.

\section{Firm Size}

Firm size is a characteristic of a company within its relationship with the company's structure. Firm size is measured by the natural logarithm of total assets owned by the company. The definition 
of total assets is all resources controlled by the company as a result of past and expected transactions will provide economic benefits for the company in the future. Companies that have assets with large amounts or referred as big companies that will get more attention from the other parties, such as investors, creditors, government and economic analysis are compared with a small company.

\section{Sales Growth}

Sales are the most important factor in the company, because from the sale of the company will get a profit or loss. The company certainly expects a high level of sales and increase year by year. Company should know sales from the previous year, so the company can optimize their existing resources. By knowing how much sales growth, company can predict how much profit will be obtained for that year.

\section{Liquidity}

Liquidity is one of ratio that is often used in analyzing financial statements, this ratio compares short-term liabilities with short-term resources available to fulfill these obligations. In this research, the researchers use the current ratio to measure the liquidity variable. There are two various ratios of liquidity ratio include:

\section{Current Rasio}

This ratio shows the company's ability to pay its short-term obligations using its current assets.

2. Acid-Test (Quick) rasio

This ratio shows the company's ability to meet short-term obligations with the most liquid assets.

\section{Leverage}

If the company is not able to produce sufficient profitability, then the company will not be able to maintain their business. Therefore, company needs sources of funds from outside the company to maintain the continuity of their business. Meeting the needs of funds originating from outside the company can be obtained from borrowing funds to creditors such as banks, non- bank financial institutions, or the company can issue shares and bonds to be offered to the public.

Fulfillment of funding sources through debt, will affect the level of leverage of the company, because leverage is a ratio that used to measure how much of assets that company have from their debts. If the company have high leverage ratio, it indicated that was not good, because the company running their operations from debt.

\section{RESEARCH METHODS Research Design}

This research is approach by quantitative approach. The quantitative approach is an approach that uses data in the form of numbers. This study aims to examine the effects of variables certain to other variables. The data used in this research is secondary data obtained from the Indonesia Stock Exchange (IDX), which is an annual report issued by 2 FMCG companies in Indonesia, PT. Indofood CBP Sukses Makmur Tbk and PT. Mayora Indah Tbk from 2011-2017 (7 years).

\section{Variables and Measurement}

\section{Dependent Variable ( $\mathrm{Y}$ )}

The dependent variable is the variable that is affected by the independent variable. The researchers want to know the effect of firm characteristics on Profitability, so the dependent variable in this research is Profitability. The dependent variable will be called as (Y). According to the previous research by Charles, Ahmed, and Joshua (2018), the Profitability is measured by ROS (Return on Sales).

$$
\text { Return on Sales }=\frac{\text { Operating Profits }}{\text { Net Sales }}
$$

\section{Independent Variable (X)}

The Independent Variable in this research is the firm characteristics that proxied by firm age, firm size, sales growth, liquidity and leverage.

\section{Firm Age (X1)}

Firm age is the length of time during which a being or thing has existed. We measured firm age by logarithm of number of years in operation. 
Firm age $=\log ($ age of firm)

\section{Firm Size (X2)}

The Firm size variable is measured by the natural logarithm of the total assets of company.

$$
\text { Firm Size }=\text { LN (Total Asset })
$$

\section{Sales Growth (X3)}

For the third independent variable, the sales growth measured by the percentage increase of the sales. The formula is:

Sales Growth $=\frac{\text { (Sales Current Year-Sales Previous Year) }}{\text { Sales Previous Year }} \times 100$

\section{Liquidity (X4)}

The fourth independent variable is liquidity, in this research the liquidity ratio is measured by current ratio, which is total current asset divided by total current liabilities.

$$
\text { Current Ratio }=\frac{\text { Total Current Assets }}{\text { Total Current Liabilities }}
$$

\section{Leverage (X5)}

The last independent variable in this research is the leverage ratio, which is measured by debt ratio, the total liabilities divided by total assets.

$$
\text { Debt Ratio }=\frac{\text { Total Liabilities }}{\text { Total Assets }}
$$

\section{Data Analysis Method}

There are several data analysis for this research, included Descriptive Statistical Test, Normally Test, Determination of Coefficient Test, and Partial Test. The regression model of this research:

$Y=\beta 0+\beta 1 F A G i+\beta 2 F S Z i+\beta 3 S A G i+\beta 4 L I Q i+\beta 5 L E V i+\varepsilon i \quad(1)$
Where:

$\begin{array}{ll}\text { Y } & : \text { Profitability } \\ \text { FAG } & : \text { Firm Age } \\ \text { FSZ } & : \text { Firm Size } \\ \text { SAG } & : \text { Sales Growth } \\ \text { LIQ } & : \text { Liquidity } \\ \text { LEV } & : \text { Leverage } \\ \beta 0 & : \text { Constant } \\ \beta 1-\beta 5 & =\text { Regression Coefficient } \\ \varepsilon & : \text { Error }\end{array}$

\section{RESULTS AND DISCUSSION}

\section{Descriptive Statistical Test}

Descriptive Statistics used to describe the data view from the minimum value, maximum value, mean, standard deviation, and amount of data. The result from descriptive statistics test of the variables in this research described through this following table:

Profitability as the dependent variable has 0,0629 as the lowest value and 0,1466 as the highest value. The mean of profitability from 14 observation is 0,11613 with the standard deviation is 0,02289 . From the 14 observation, Firm Age has 0,30103 as the lowest value and 1,60206 as the highest value. Mean of the firm age is 1.1127 and standard deviation is 0.4941 . From the 14 observation, firm size has 29,518 as the lowest value and 31,0848 as the highest value. Mean of firm size is 30,3636 with standard deviation is 0.4936 . From the 14 observation, sales growth has 0,03309 as the lowest value and 0.23829 as the highest value. Mean of sales growth is 0.1293 with standard deviation is

Table 1. Descriptive Statistics Test Result Residual Statistics

\begin{tabular}{|c|c|c|c|c|c|}
\hline & N & Minimum & Maximum & Mean & Std. Deviation \\
\hline Profitability & 14 &, 06290 &, 14665 &, 1161300 &, 02289000 \\
FirmAge & 14 &, 30103 & 1,60206 & 1,1127479 &, 49414641 \\
FirmSize & 14 & 29,51810 & 31,08480 & 30,3646429 &, 49364504 \\
SalesGrowth & 14 &, 03309 &, 23829 &, 1293336 &, 06679150 \\
Liqudity & 14 & 2,08994 & 2,87107 & 2,4156671 &, 22490183 \\
Leverage & 14 &, 29647 &, 63262 & & \\
Valid N (listwise) & 14 & & & & \\
\hline
\end{tabular}

Source: Data processed by SPSS 22, 2017 
0.06679. From the 45 observation, liquidity has 2,08994 as the lowest value and 2,871 as the highest value. Mean of liquidity is 2,4157 with standard deviation is 0,2249 . From the 14 observation, leverage has 0,29647 as the lowest value and 0,6326 as the highest value. Mean of leverage is 0,466 with standard deviation is 0,121397 .

\section{Normality Test}

The purpose of normality test is to know whether the regression model both of the dependent variable and independent variable have normal distribution data or not. The result from normality test of the variables in this research described through this following table:

Table 2. Normality Test Result One-Sample Kolmogorov-Smirnov Test

\begin{tabular}{|lr|r|}
\hline & & $\begin{array}{r}\text { Unstandardized } \\
\text { Predicted Value }\end{array}$ \\
\hline $\mathrm{N}$ & & 14 \\
Normal Parameters ${ }^{\mathrm{a}}{ }^{\mathrm{b}}$ & Mean &, 1161300 \\
& Std. Deviation &, 02130491 \\
Most Extreme Differences & Absolute &, 134 \\
& Positive &, 086 \\
Test Statistic & Negative &,- 134 \\
Asymp. Sig. (2-tailed) & &, 134 \\
\end{tabular}

Source: Data processed by SPSS 22, 2017

The Normality Test of data shows the value of the asymp significance is 0,2 which is more than 0,05 . It means the multiple regression model has normal distribution data.

\section{Determination of Coefficient}

Determination of coefficient describe the percentage of independent variable able to explain the dependent variable. The result from determination of coefficient test of the variables in this research described through this following table:

In this research, determination of coefficient in the regression model can see through the Adjusted $\mathrm{R}$ Square is 0,783 . It means the independent variables in this research which are firm age, firm size, sales growth, liquidity, and leverage is able to explain the dependent variable which is profitability is $78,3 \%$. While the residual value which is $21,7 \%$ is variation of the other independent variables that can affect to the profitability, but not include in the regression model in this research.

\section{Partial Test}

Partial test shows the ability of each independent variable effect to the dependent variable. The result from determination of partial test of the variables in this research described through this following table:

Table 3. Determination of Coefficient Test Result Model Summary

\begin{tabular}{|c|c|c|c|c|c|}
\hline Model & $\mathbf{R}$ & $\begin{array}{c}\text { R } \\
\text { Square }\end{array}$ & $\begin{array}{c}\text { Adjusted } \\
\text { R Square }\end{array}$ & $\begin{array}{c}\text { Std. Error of } \\
\text { the Estimate }\end{array}$ & $\begin{array}{c}\text { Durbin- } \\
\text { Watson }\end{array}$ \\
\hline 1 &, $931^{\mathrm{a}}$ &, 866 &, 783 &, 01066939 & 2,600 \\
\hline
\end{tabular}

a. Predictors: (Constant), Leverage, Liqudity, SalesGrowth,

FirmSize, FirmAge

b. Dependent Variable: Profitability

Source: Data processed by SPSS 22, 2017

Table 4. Partial Test Result Coefficients

\begin{tabular}{|c|c|c|c|c|c|c|c|c|}
\hline & \multirow[b]{2}{*}{ Model } & \multicolumn{2}{|c|}{$\begin{array}{l}\text { Unstandardized } \\
\text { Coefficients }\end{array}$} & \multirow{2}{*}{$\begin{array}{c}\begin{array}{c}\text { Standardized } \\
\text { Coefficients }\end{array} \\
\text { Beta }\end{array}$} & \multirow[b]{2}{*}{$\mathbf{t}$} & \multirow[b]{2}{*}{ Sig. } & \multicolumn{2}{|c|}{ Collinearity Statistics } \\
\hline & & B & Std. Error & & & & Tolerance & VIF \\
\hline \multirow[t]{6}{*}{1} & (Constant) &,- 494 & 618 & &,- 800 & ,447 & & \\
\hline & Firm Age & ,058 & ,018 & 1,259 & 3,265 & ,011 & 112 & 8,897 \\
\hline & Firm Size & ,017 & 018 & ,369 & 960 & ,365 & 113 & 8,823 \\
\hline & Sales Growth &,- 019 & ,066 &,- 054 &,- 282 & ,785 & ,451 & 2,216 \\
\hline & Liqudity & ,059 & ,023 & ,579 & 2,521 & ,036 & 317 & 3,154 \\
\hline & Leverage &,- 243 & 107 & $-1,291$ & $-2,278$ & ,052 & ,052 & 19,209 \\
\hline
\end{tabular}

a. Dependent Variable: Profitability Source: Data processed by SPSS 22, 2017 


\section{Firm Age and Profitability}

The age of firm measured by the natural logarithm of difference between the observation year and established year of the firm. The age of a company shows how long the company has been operating. The significance value of firm age in the Table 4 is 0,011 which is $\leq 0,05$. It means Ha is accepted; the firm age has significant effect on profitability.

The result of this research is in line with previous research by Sumaira and Amjad (2013) that the firm age effect on profitability. The longer a company established shows that the company has more experience gained to run their operations, also more knowing about the trending of market demand from year to year and it can make the company improve their strategies to reach more wider market to generate more profits.

\section{Firm Size and Profitability}

Firm size measured by logarithm of total assets of the firm. The greater the amount of assets in a company show the greater size of the company. The significance value of firm size in the Table 4 is 0,365 which is $>0,05$. It means $\mathrm{Ha}$ is rejected; the firm size has no effect on profitability.

Large companies have more complex production process than small companies and investments in physical capital needed to produce a product in production activities also require more costs that will affect profits. The result of this research is in line with previous research by Sari, Juwita, and Elizabeth (2017) that the firm size not affect the profitability. Large companies tend to have the ease of obtaining loan funds that can be used for additional assets to support the operational activities to be better and generate more profits, but that is only if the company can manage these assets effectively and efficiently so the use of assets can be maximized.

\section{Sales Growth and Profitability}

Sales growth measured by the percentage of increasing sales in turnover. By knowing the sales growth, the company can predict profit that will be obtain and also make their projected sales budget. The significance value of sales growth in the Table 4 is 0,785 which is $>0,05$. It means Ha is rejected; the sales growth has no effect on profitability.

The increasing of sales growth means the company using their assets and resources efficient and optimal to maintain company's position and their operational and it will make the profit. The research are in line with prior research by Rofiah, Mardani, and Wahono (2017) which found that the sales growth are not main factor that effecting the profitability of a firm because increasing amount of sales accompanied by increasing amount of operating expenses, it makes the profitability not significantly increasing. There is another factors sales growth are not affected to the profitability, such as the sales of current year are decrease from the previous year.

\section{Liquidity and Profitability}

Liquidity ratio describes the ability of a firm to pay off all of their liabilities. This research measured the liquidity of the firm using current ratio, it calculated the amount of current assets to current liabilities. The significance value of liquidity ratio in the Table 4 is 0,036 which is $\leq$ 0,05 . It means $\mathrm{Ha}$ is accepted; the liquidity ratio has significant effect on profitability.

The results of this research are in line with previous research by Rofiah, Mardani, and Wahono (2017). The liquidity level of a firm shows the ability of a firm to pay off its short-term debts by using assets and showing the efficiency in firm's operating cycle in converting products into cash. High liquidity level of a firm will affect to its ability to produce profits faster.

\section{Leverage and Profitability}

Leverage ratio used to measure the extent to which a company is financed by debt. In this research, the leverage ratio measured by total liabilities to total assets. The significance value of leverage in the Table 4 is 0,05 which is $\leq 0,05$. It means $\mathrm{Ha}$ is accepted; the leverage has significant effect on profitability. 
Leverage shows how much the total assets of the firm are financed by debt; high amount of leverage means the majority of assets owned by the firm are obtained by debt. The greater amount of loan capital used in generating profits will make more debt because of the additional funds from the loan will add assets but on the other hand it increases the company's debt, so that it will reduce the profitability of the company (Rofiah, Mardani, and Wahono: 2017). Increasing loans also generate an increasing interest expense and that will further reduce the company's profits, so the leverage ratio has negative influence significantly to the profitability.

\section{CONCLUSION, LIMITATION, AND RECOMMENDATIONS}

Research was conducted to find out the effect of firm characteristics proxied by firm age, firm size, sales growth, liquidity, and leverage on profitability proxied by return on sales by using empirical data from PT Indofood CBP Sukses Makmur Tbk and PT Mayora Indah Tbk. The results of this study concluded that the firm age, liquidity, and leverage have significant effect on profitability. However, the firm size and sales growth has no effect on profitability.

The limitations that the author obtained in this research is the time to do research is too short, so the author cannot observe more companies in Fast Moving Consumer Goods (FMCG). It makes the results of this research are less able to describe the actual state of affairs the entire FMCG company in Indonesia.

The recommendations that can be considered by next researchers next is the next researchers expected to more examine the other variables that can influencing profitability, so the research will not only analyze the characteristics of the company. In addition, researchers also can extend the object to observe in the research so it will make there are more firms to observe and including more variety of industry sectors.

\section{REFERENCES}

Annisa, R (2016). Pengaruh Rasio Aktivitas, Rasio Leverage, Ukuran dan Umur Perusahaan terhadap Profitabilitas (Suatu Studi pada perusahaan telekomunikasi yang terdaftar di Bursa Efek Indonesia)

Belkaoui, A. R. (2006). Accounting Theory: Teori Akuntansi. Salemba Empat, Jakarta, Buku 1, Edisi kelima.

Charles, Ahmed, Joshua (2018). Effect of Firm Characteristics on Profitability of Listed Consumer Goods Companies in Nigeria. Journal of Accounting, Finance and Auditing Studies 4/2, 14-31

Lestari, E (2017). The Influence of Effectiveness of Board of Commissioner and Audit Committee, Ownership Structure, and Audit Quality on Earning Management. (Empirical Study on Property and Real Estate Industry which is listed on the Indonesian Stock Exchange in 2013-2015).

Miswanto, Abdullah, and Suparti (2017). Pengaruh Efisiensi Modal Kerja, Pertumbuhan Penjualan, dan Ukuran Perusahaan terhadap Profitabilitas Perusahaan. Jurnal Bisnis dan Ekonomi, Vol. 24, No. 2, pp 119-135.

Putra and Badjra (2015). Pengaruh Leverage, Pertumbuhan Penjualan, dan Ukuran Perusahaan terhadap Profitabilitas. E-Jurnal Manajemen Unud.

Rofiah, Mardani, and Wahono (2017). Pengaruh Efisiensi Modal Kerja, Likuiditas dan Solvabilitas terhadap Profitabilitas pada Perusahaan Food and Beverage yang terdaftar Di Bursa Efek Indonesia (BEI). EJournal Riset Manajemen. 
Sari, Juwita, and Elizabeth (2017). Pengaruh Intellectual Capital dan Ukuran Perusahaan terhadap Profitabilitas pada Bank Umum Syariah di Indonesia Periode 2011-2014.

Sumaira and Amjad (2013). Determinants of profitability panel data evidence from insurance sector of Pakistan. Elixir International Journal.

Wahyuni and Pujiharto (2015). Mengukur Kinerja "Intellectual Capital" dengan Model iB-VAIC: Implementasi Resources Based Theory pada Perbankan Syariah Di Indonesia. 